\title{
Mineral Characterization and Geometallurgy of Diamond Deposits and Mantle Materials Using QEMSCAN ${ }^{\circledR}$ Techniques
}

\author{
K. Hoal ${ }^{1}$, P. Botha ${ }^{2}$, A. Forsyth ${ }^{3}$, A. Butcher ${ }^{3}$, and C. Palmer ${ }^{4,5}$ \\ ${ }^{1}$ Advanced Mineralogy Research Center, Colorado School of Mines, Golden, Colorado, USA \\ ${ }^{2}$ Intellection Corporation, Westminster, Colorado, USA \\ ${ }^{3}$ Intellection (Pty) Ltd, Milton, Queensland, Australia \\ ${ }^{4}$ CSIR Natural Resources and the Environment, Johannesburg, South Africa \\ ${ }^{5}$ Gem Diamond Technical Services (Pty) Ltd, Johannesburg, South Africa
}

\section{Introduction}

Unlike the metals and energy industries, the diamond industry is only beginning to realize the economic benefits of improved mineral characterization and geometallurgical analysis. Benvie (2007) demonstrated the use of EDS-based SEM techniques such as QEMSCAN $^{\circledR}$ in kimberlites, and showed how image analysis can enhance the determination of processing parameters such as liberation criteria. These quantitative mineralogy techniques provide greater understanding of material attributes such as mineral distribution, textural associations, and alteration, which can be correlated with physical tests. For diamond deposits, geometallurgical analysis through quantitative mineralogy refers to identifying the attributes of the material at present, the hardness, grindability, and potential processing characteristics that are ultimately a function of the mineralogy and geology of the deposit. The distribution of megacrysts, silicification, and serpentinization, for example (Figures 1, 2), affects the processing of the diverse phases of a kimberlite and the final recovery of diamonds. The degree to which these variables can be predicted impacts the final risk and cost effectiveness of a project (Hoal, 2008).

We report on preliminary results of QEMSCAN ${ }^{\circledR}$ quantitative mineralogy analysis conducted on three

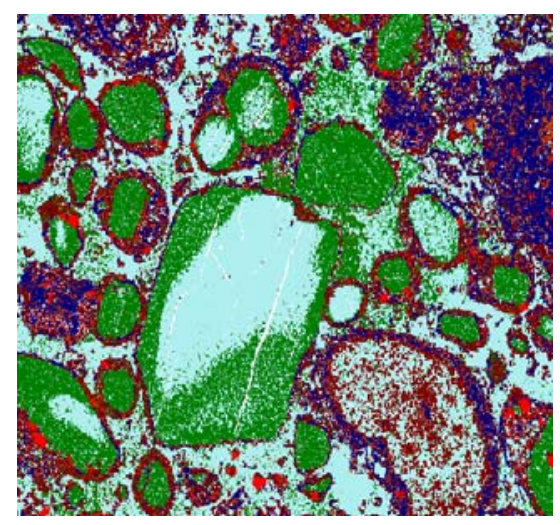

Fig. 1. Thin section of Letšeng Satellite Pipe kimberlite, with olivine xenocrysts and phenocrysts, serpentine (green) and chloritic (blue) groundmass, and coarse mineral aggregates. diamond-related material types: kimberlite from the Letšeng Satellite Pipe (C. Palmer, pers. comm.), mantle xenoliths from Premier (Cullinan; Hoal, 2003), and garnet concentrates from Kimberley (Spath, 1991). In each case, a specific project scope was identified, the appropriate pixel spacing was determined on the basis of texture and grain size, and the Species Identification Protocol (SIP) list was developed as a function of the known compositional variations of the mineralogy. The data are readily extractable for data interrogation and assessment, and are reported through the use of false-colored images.

\section{Kimberlites}

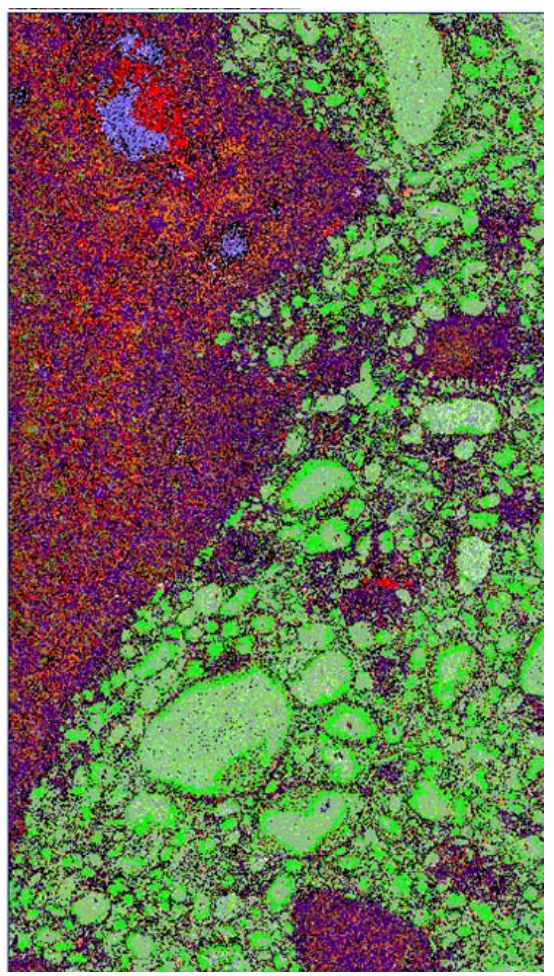

Fig. 2. Thin section of Letšeng Satellite Pipe kimberlite showing textural and mineralogical variations dominated by serpentine (green) and different phases (red-purple) of the kimberlite. 
Kimberlites represent the most important geomet material in a diamond mine, and its variable properties influence extraction rates and grades. Three kimberlite samples from the Letšeng Satellite Pipe were analyzed to examine the mineralogical and textural variations throughout the kimberlites. The mineral distribution particularly applies to hard kimberlitic material, and influences the degree of crushing required to liberate potentially large stones. Preliminary information from this study indicates a chloritic phase is dominant in the groundmass together with a Ca-Si wollastonitic composition. The example mineral list (Figure 3) used in this analysis is being further refined and breakage tests conducted to assess the importance of silicates in the groundmass to hardness.

\begin{tabular}{|l|r|}
\hline Mineral Name & Area \% \\
$\square$ Background & 0.2 \\
$\square$ Olivine & 0.8 \\
Pyroxene & 40.5 \\
Tremolite-Actinolite & 10.2 \\
$\square$ Chlorite & 10.2 \\
$\square$ Talc & 0.7 \\
$\square$ Serpentine & 29.4 \\
Wollastonite & 1.5 \\
$\square$ Hornblende & 0.2 \\
$\square$ Biotite/Phlogopite & 2.9 \\
$\square$ Sphene & 0.3 \\
$\square$ Perovskite & 2.1 \\
$\square$ Ilmenite & 0.1 \\
$\square$ Fe Oxides & 0.0 \\
Chromite & 0.1 \\
$\square$ Fe Sulphide & 0.0 \\
$\square$ Calcite & 0.2 \\
$\square$ Apatite & 0.2 \\
$\square$ Siderite & 0.0 \\
$\square$ Other & 0.5 \\
\hline
\end{tabular}

Fig. 3. Example mineral list used for the kimberlites and estimates of areal distribution of phases identified by x-ray patterns.

\section{Mantle Xenoliths}

Metasomatized peridotite xenoliths from Premier (Cullinan) mine (Figures 4, 5) were analyzed to gain an

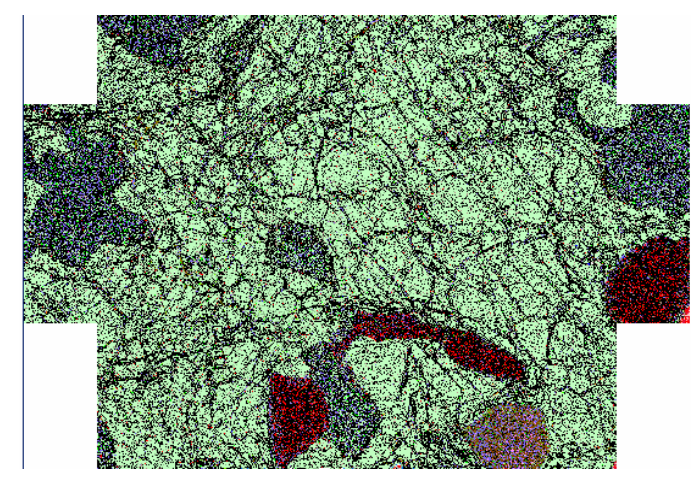

Fig. 4. Lherzolite xenolith showing altered orthopyroxene (blue patches) in olivine (green) and the distribution of metasomatic diopside (purple-red). improved understanding of fabrics, assemblages, and the distribution of metasomatically formed diopside, bitotite, and amphibole. These xenoliths differ from similar peridotites at Kimberley in that the mica present is biotite instead of phlogopite and the amphibile is pargasite instead of K-richterite (Hoal, 2003). The results include more readily identifiable metasomatic phases, improved understanding of mineral distibutions, reaction relationships, and textures, and a data set that can be queried to search for key phases.

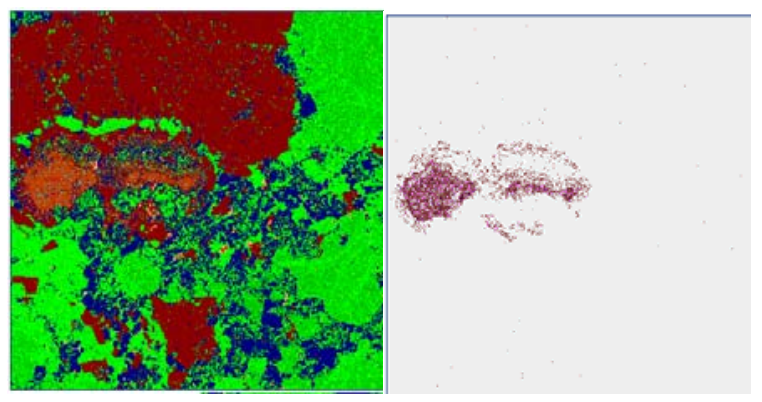

Fig. 5. Iron-rich peridotite from Premier (Cullinan), showing the distribution of Fe-biotite (red) and diopside (blue); the image at right shows the ditribution of pargasitic hornblende (Hoal, 2003).

\section{Concentrate Garnets}

Concentrate garnets were analyzed to determine the degree to which QEMSCAN ${ }^{\circledR}$ analysis can be used to expedite assessing the large volumes of mineral grains produced during exploration programs. As a highvolume technique specifically geared toward particle analysis, the system uses four detectors and specialized software capabilities to make up to 150 x-ray determinations per second. This capability enables rapid $\mathrm{x}$-ray-based analysis of thousands of grains from the micron scale to the centimeter scale.

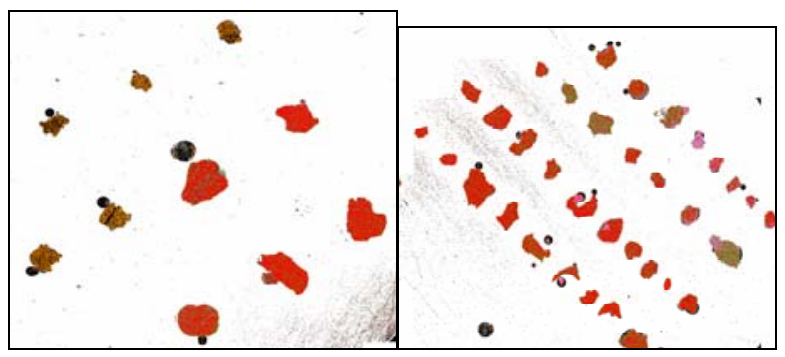

Fig. 6. Garnet concentrates from Premier (Cullinan) (left five, brown), Jagersfontein (left five, red), and Kimberley (right). The garnets include G9, G10, and knorringitic compositions (Spath, 1991).

Preliminary results indicate garnet compositions can be mapped by defining subpopulations based on peak height ratios, and using the full compositional spectrum of the grains. We are doing development work to further refine these definitions and to develop a 
species-specific garnet SIP file to map variations within each grain, in order to complement the single determinations made by electron microprobe. One observation from the raw data set is the distinction between localities: the images of garnet populations from Premier differ from Kimberley and Jagersfontein, in part a function of $\mathrm{Ca} / \mathrm{Mg}$ abundances apparently irrespective of previous G9/G10 determination.

\section{Geometallurgical Analysis}

Geomet combines geological data such as lithotypes, structures, domain mapping, and alteration distribution with mineral characterization, geotechnical analysis, and knowledge of processing methods. It is increasingly employed in metal deposits for improving downstream decision making, reducing operational risk, and increasing project value (Hoal, 2008). Jakubec (2004) and Jakubec et al. (2004) employed similar concepts for kimberlites using geotechnical parameters to identify physical variations in kimberite, with demonstrated benefits for feasibility studies and mine planning and design (Figure 7).
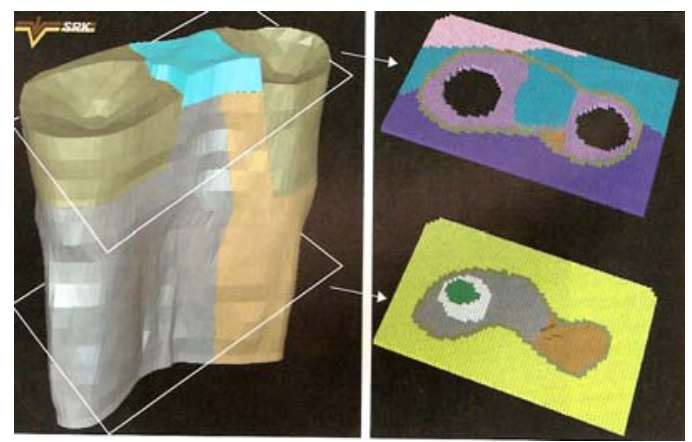

Fig. 7. Geotechnical domain model by Jakubec (2004).

The mineral characterization of kimberlitic materials (eg., Benvie, 2007) is the critical link between geology, geotech (Jakubec, 2004, Jakubec et al., 2004), and process development. It requires samples that have spatial information (blastholes or drill cores, for example), and enough material to analyze and test at the bench scale (Figure 8). Relatively soft, serpentinized kimberlite can be predictably simple to process, although the presence of large silicate megacrysts such as olivine may complicate a comminution circuit. The complete serpentinization of such megacrysts, however, while not visible to the eye, may result in little material difference in hardness between megacryst and matrix.

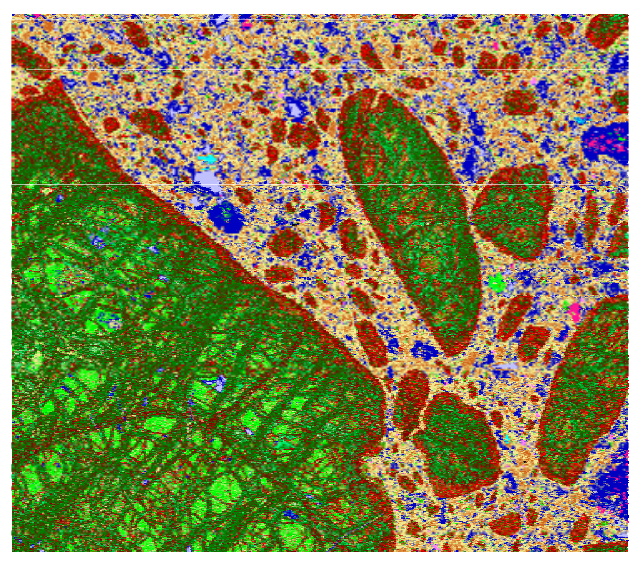

Fig. 8. A QEMSCAN ${ }^{\circledR}$ image of a rock slice, a $10^{2} \mathrm{~cm}$ block of olivine megacryst-bearing kimberlite, Kimberley, South Africa (courtesy Intellection Pty Ltd). Larger samples such as this can be geotechnically tested to provide mineral data for block models.

Geomet is the tool for predicting the development process flowsheet of diamond deposits, and mineral characterization is the major component of geomet analysis. Ongoing research by our geomet group is exploring the link between mineralogy, texture, and breakage characteristics in a number of ore, energy, and environmental materials. Kimberlites and diamond-related materials form an important part of this effort.

\section{References}

Benvie, B., 2007, Mineralogical imaging of kimberlites using SEM-based techniques, Minerals Engineering, 20, 435-443.

Hoal, K.O., 2003, Samples of Proterozoic ironenriched mantle from the Premier kimberlite, Lithos, 71, 259-272.

Hoal, K.O., 2008, Getting the geo into geomet, SEG Newsletter, Society of Economic Geologists, no 73, April, p. 1, 11-15.

Jakubec, J., 2004, Role of geology in diamond project development, Lithos, 76, 337-345.

Jakubec, J., Long, L., Nowicki, T., and Dyck, D., 2004, Underground geotechnical and geological investigations at Ekati Mine-Koala North: case study, Lithos, 76, 347-357.

Spath, A., 1991, Garnet composition in mantle xenoliths and heavy mineral concentrates from some South African kimberlite pipes, University of Cape Town, research project report, 37 pp. 